

KAVRAMSAL MAKALESI

\title{
Boş Zaman, Rekreasyon ve Turizm Kavramları Arasındaki İlişkinin Karşılaştırmalı Bir Analizi ${ }^{1}$
}

Dr. Öğr. Üyesi Yakup ÖZTÜRK, Çankırı Karatekin Üniversitesi, Ilgaz Turizm ve Otelcilik Yüksekokulu e-mail:yakupozturk@karatekin.edu.tr

ORCID: https://orcid.org/0000-0003-1495-9979

\section{Öz}

Boş zaman etkinlikleri olarak turizm ve rekreasyonel etkinlikler insanların hayat kalitesini artırarak, tatmin düzeylerini etkilemektedir. Gerek rekreasyon gerekse turizm katılımcıların gönüllü olarak seçtikleri ve boş zamanlarını değerlendirdikleri etkinlikleri kapsar. Günümüzde birbirini tamamlayan iki kavram olarak değerlendirilen turizm ve rekreasyon terimlerinin, belirgin birçok açıdan farklı olmalarına rağmen aynı anlamda kullanılabildiği görülmektedir. Bu çalışmada, turizm ve rekreasyon kavramları ele alınarak, bu kavramlar arasındaki ilişki karşılaştııılarak analiz edilmiştir. Çalışma rekreasyon ve turizm kavramlarının birbiri ile yakın ilişkili olduğu ancak, aynı anlamda kullanımının kabul edilemeyeceği görüşünü destekler niteliktedir.

Anahtar Kelimeler: Turizm, Rekreasyon, Turizm ve Rekreasyon İlişkisi.

Makale Gönderme Tarihi: 1.10.2018

Makale Kabul Tarihi: 28.12.2018

\section{Önerilen Atıf:}

Öztürk, Y. (2018). Boş Zaman, Rekreasyon ve Turizm Kavramları Arasındaki İlişkinin Karşılaştırmalı Bir Analizi, Sosyal, Beşeri ve İdari Bilimler Dergisi, 1(2):31-42.

(C) 2018 Sosyal, Beşerî ve İdari Bilimler Dergisi.

\footnotetext{
${ }^{1}$ Bu çalışma 04-05 Mayıs 2015 tarihlerinde Saraybosna'da düzenlenen I. Uluslararası Sosyal Bilimler Araştırmaları Kongresi’nde sunulan “Rekreasyon ve Turizm Kavramları Arasındaki İlişkinin Karşılaştırmalı Bir Analizi” başlıklı bildirinin genişletilmiş halidir.
} 


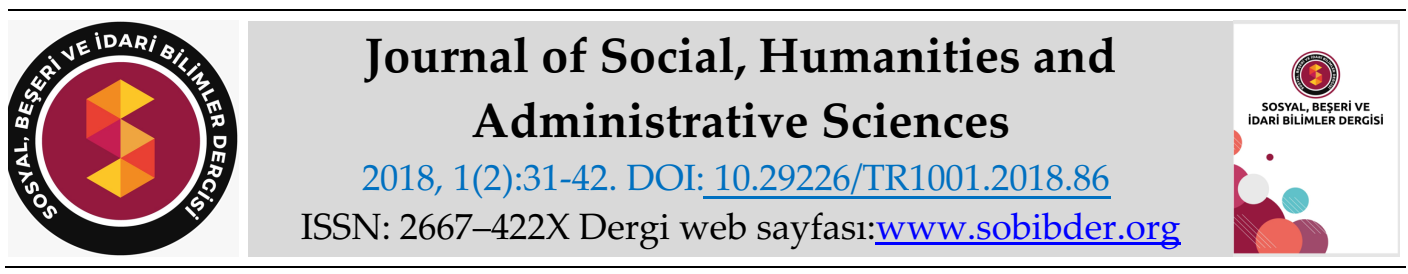

\title{
CONCEPTUAL PAPER
}

\section{A Comparative Analysis of the Relationship Between Leisure, Recreation and Tourism Concepts}

Dr. Yakup ÖZTÜRK, Çankırı Karatekin University, Ilgaz Tourism and Hotel Management School e-mail:yakupozturk@karatekin.edu.tr

ORCID: https://orcid.org/0000-0003-1495-9979

\begin{abstract}
Tourism and recreational activities as leisure activities affect the satisfaction levels of people by increasing the quality of life. Both recreation and tourism include activities that participants choose voluntarily and evaluate their leisure time. The relation between recreation and tourism is mentioned in the literature. It is seen that tourism and recreation terms, which are considered as two complementary concepts, can be used in the same sense even though they are different in many respects. In this study, the concepts of tourism and recreation were examined and the relationship between these concepts was analyzed. The study supports the view that the concepts of recreation and tourism are closely related, but their use cannot be accepted in the same sense.
\end{abstract}

Keywords: Tourism, Recreation, Tourism and Recreation Relationship.

Received: 1.10 .2018

Accepted: 28.12.2018

\section{Suggested Citation:}

Öztürk, Y. (2018). A Comparative Analysis of the Relationship Between Leisure, Recreation and Tourism Concepts, Journal of Social, Humanities and Administrative Sciences, 1(2):31-42.

(c) 2018 Sosyal, Beşerî ve İdari Bilimler Dergisi. 


\section{Gíriş}

Turizm ve rekreasyon ilişkisi, mutlu olma, eğlenme, boş zaman, hoşlanma gibi kavramların sık sık birlikte ve ortak kullanılması nedeniyle çoğu zaman bu iki kavramın birbirini yerine kullanılması sonucunu doğurmaktadır (Karaküçük, 2008: 173). Turizm ve rekreasyonun ortak noktaları olduğu gibi her ikisinin birbirinden farklı yönleri de vardır. Giderek daha fazla iç içe kullanılan turizm ve rekreasyon kavramlarının ve faaliyetlerinin hem birleştirilmesi ve hem de birbirinden ayrılması zorlaşmaktadır. Rekreasyon ve turizm kavramlarının net olarak anlaşılabilmesi için boş zamana ilişkin yaklaşımların incelenmesi gerekmektedir. Bu anlamda, boş zaman üzerine birçok farklı yaklaşım bulunmaktadır. Bu yaklaşımlar araştırmacıların kendi disiplinlerindeki teorik alt yapı üzerine bina edildiğinden, tanımsal olarak boş zaman kavramının keskin bir biçimde hatlarının çizilmesi mümkün olamamıştır. Ayrıca boş zaman ve buna bağlı gelişen kavramların, başlangıçta sosyolojik temelli teoriler üzerinden geliştiği bilinse de günümüzde yalın bir teorik bakış açısıyla ele alınmaması gerekmektedir (Metin, Kesici ve Kodaş, 2013: 5023).

Turizm aktiviteleri ile boş zaman arasında çok yoğun bir nedensellik söz konusudur. İnsanlar çalışma hayatından arta kalan boş zamanlarının bir kısmını veya tamamını kişisel gelirlerine bağılı olarak turizm faaliyetleri içerisinde değerlendirmektedirler (Erol, 2003: 7). Turizm, boş zaman değerlendirmeyle ilgili olay ve ilişkileri kapsamaktadır. Boş zaman değerlendirmenin, turizm tanımlarında yer alması 1970'li yıllara rastlamaktadır. Bu konuda Ernst Spatt, turizmi dinlenme ve onunla ilgili ihtiyaçların tatmini sebebiyle boş zamanların değerlendirilmesinden ortaya çıkan ilişiler, etkinlikler olarak göstermektedir. Boş zamanın insanın zindelik ve sağlığına kavuşması yanında çok hareketli bir tatil yapmaya da harcanabileceğini savunmaktadır (Hazar, 2003: 17).

Çalışmanın yanında, insanların kendilerince özgür olarak kullanabilecekleri boş zamanın önemli bir ihtiyaç olduğu görüşünün yaygınlaşması ve uygulamaya konulmuş olması, günümüz gelişmekte olan ve özellikle gelişmiş ülkelerde, rekreasyon aktiviteleri olarak yeni yaşam biçimleri yaratmıştır. Bu yaşam biçimlerini etkileyen rekreasyon uygulamaları hem çeşit hem de katılan insanlar bakımından sürekli zenginleşmiştir. İşte, bu rekreasyon uygulamaları etkinliklerinin en önemli aşamalarından birini “Turizm” oluşturmaktadır (Karaküçük, 1999: 185).

Kuramsal inceleme niteliğindeki bu çalışmada, birbirini tamamlayan rekreasyon ve turizm kavramları irdelenmiştir. Bu çerçevede öncelikle zaman ve boş zaman kavramları açıklanmış, daha sonra rekreasyon ve turizmin benzerlik ve farklılık gösteren özellikleri ortaya konulmuştur. Böylelikle, turizm ve rekreasyon kavramlarının anlam ve özelliklerine ilişkin açılama yapılarak terminolojide yaşanan kavram karmaşasının önüne geçilmesi amaçlanmıştır.

\section{ZAMAN KAVRAMI}

Günümüzde oldukça fazla kullandığımız zaman kavramı aslında insanoğlunun yarattığı, hayatın akışın bir düzen içerisinde yürütmek amacı ile oluşturulmuş ve kullanılagelmiştir. Zaman, insan için yaradılışından bu yana büyük önem taşıyan bir olgudur. İnsanın gelişmesinde, hayat akışını şekillendirmesinde, günlük faaliyetlerini düzenlemesinde ve hangi alanda olursa olsun mesleki başarısında zaman anlayışının payı büyüktür (Karaküu̧ük, 1999: 3).

Zaman kavramı, günümüzde de olduğu gibi tarihler boyunca insan yaşamını dikkat çekici bir şekilde etkileyen ve aslında düzenleyen de bir olgudur. Güven ve Yeşil (2011) zamanı, önüne 
geçilmez bir şekilde, sabit bir hızla akıp geden ve tüm bireylerin eşit şekilde sahip olduğu önemli bir değer olarak tanımlarken, ayrıca insanın duyu organları ile algılamadığı fiziksel, felsefi, psikolojik ve sosyolojik boyutları olan bir olgu ve gerçek tanımlamasını yapmışlardır (Gül, 2014: 3).

Hayatımızda bu denli önemli bir role sahip olan ve "zaman nedir?" diye sorulduğunda tam bir cevap verilemeyen bu kavramı açıklayabilmek için çeşitli yazar, araştırmacı tarafından birçok tanımı yapılmıştır. Ancak zaman göreceli bir kavramdır. Bu doğrultuda genel ve net bir tanım yapmak mümkün olmamaktadır (Türkmen, 1999: 2).

Zaman kavramı belki de en basit olarak saatler, günler ve haftalar olarak tanımlanabilir (Karaküçük ve Gürbüz, 2007: 16). Sözlük anlamı olarak zaman; bir iş veya oluşun içinde geçtiği, geçeceği veya geçmekte olduğu süre veya vakittir. Zaman; ödünç alınamaz, kiralanamaz, satın alınamaz, çoğaltılamaz, depolanamaz, tasarruf edilemez ve iyi değerlendiremeyenlerde stres yaratır (Hazar, 2003: 6). Ayrıca; Drucker'e göre, en kıt ve eşsiz, Mackenzie'e göre son derece nazik, Tyler'e göre hayattaki en acımasız en katı element ve Laiken'e göre ise temel bir kaynak olan bir varlıktır (Karaküçük, 1999: 9).

Bazı araştırmacılar zamanı tanımlayabilmek için zamanı farklı parçalara ayırmanın gerekliliği görüşünü savunmaktadırlar (Karaküçük ve Gürbüz, 2007: 17). Garzia zamanı; a) Çalışma Zamanı, b) Çalışmaya bağlı etkinliklere ayrılan zaman, c) Yaşamı sürdürmeye yönelik etkinlikler d) Serbest zaman olarak bölümlere ayırırken, Meygeri ise; a) Temel ihtiyaçların giderilmesine ayrilan zaman (uyku, temizlik, giyinme, yemek yemek vb.), b) Serbest etkinliklere ayrılan zaman (eğlence, spor, dinlenme vb.), c) diğer etkinliklere ayrılan zaman, olarak gruplama yapmıştır (Gökmen, Açıkalın ve Koyuncu, 1985: 14-15)

\section{BOŞ ZAMAN KAVRAMI}

Boş zaman olgusu, çalışma hayatını doğrudan ilgilendiren bir konu olarak da oldukça önemlidir. Ayrıca toplumsal hayatın bir denge üzerine oturması, toplumsal sağlık ve huzurun sağlanması bağlamında da boş zaman ve kültürü önemlidir. Boş zaman ve serbest zaman kavramları çoğunlukla aynı şey olarak kabul edilmekte ve aynı tanım içerisinde yer almaktadır. Buna rağmen boş zaman ve serbest zaman kavramları arasında farklılıklar bulunmaktadır.

İzin vermek, izinli olmak anlamındaki 'Leisure', Latince 'Licer' kelimesinden türetilmiş (Cordes ve İbrahim, 2003: 4) ve alan yazında yer alan "boş zaman", "Leisure" teriminin çevirisi olarak Türkçe 'ye girmiştir (Gül, 2014: 6). Boş zaman, büyük ölçüde işin gerekliliği ve zorlayıcılığından kurtulma, özgürleşme anlamı taşır. İşin zorlayıcı dünyasından, gevşeme, ferahlama ve de kendini salıverme durumuna bir nevi kaçışı ifade eder (Aytaç, 2006: 28).

Boş zaman (Leisure) ve Serbest Zaman (Free time) iki farklı dünyada yaşar (Mannell ve Iso-Ahola, 1987: 317) ve işlevsel olarak içerikleri birbirinden oldukça farklıdır. İç içe olmalarına karşın taşıdıkları anlam ve ifade ettikleri olgu birbirinden oldukça farklıdır. Parker, serbest zaman ile boş zamanın aynı kavram olmadığını ifade etmiştir. İşten arta kalan zaman (serbest zaman) aslında birçok zorunluluk ve sorumluluğunda yerine getirildiği zamandır. Bu sorumluluklar, uyku, yeme-içme, aile ile geçirilen zaman ve temel fizyolojik gereksinimler olarak sıralanabilir. Boş zamanı tüm bunlardan ayırabilmek için daha belirgin bir tanımlamaya ihtiyaç vardır (Göral, 2013: 9). 
Birçok araştırmacı boş zaman ve serbest zaman kavramları arasında çeşitli farklar olduğunu belirtmiştir. Garzia'ya göre, her insanın serbest zamanı (free time) olabilir, ancak boş zamanı (leisure time) olmayabilir (Karaküçük, 2008: 29). Boş zaman kapsamlı bir açıdan ele alındığında, bireylerin boş zamanlarında üstlendikleri deneyimler dizisidir. Başka bir ifade ile boş zaman, insanların boş zamanlarında ilgilendikleri bir aktivite ya da birtakım yükümlülüklerden uzakta olduğu bir zamanı ifade etmektedir. Daha geniş bir perspektiften ele alındığında ise boş zaman, iş dışında harcanan zamana karşıllık gelmektedir (Argan, 2007: 13). Buna göre; boş zaman spesifik uğraşlarla harcanan zamandır ve serbest zamanın bir parçasıdır (Mieczkowski, 1990:10).

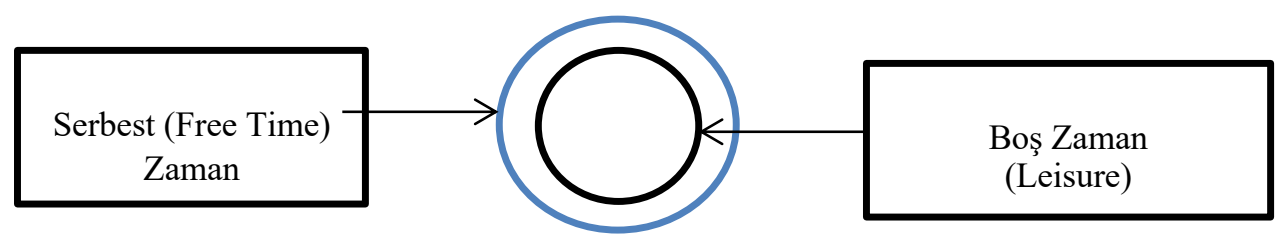

Şekil 1. Boş Zamanın Çağdaş Anlayış Biçimi

Boş zamanın geniş bir kavram olmasından dolayı bu kavramın çeşitli açılardan sınıflandırıldığ görülmektedir. Örneğin, Jensen ve Guthrie (2006), boş zamanı günlük, haftalık, yıllık ve emeklilik gibi dört farklı kategoride sınıflandırmıştır. Hazar (2003: 7) boş zamanın kullanım amacına göre sportif boş zaman, yaratıcı boş zaman, sosyal boş zaman ve turistik boş zaman olarak incelenebileceğini belirtmiştir. Benzer şekilde Torkildsen'de (2005: 47) boş zamanı kategorilere göre ayırarak sınıflandırmanın faydalı olacağını savunmaktadır. Torkildsen'e göre boş zaman dört ana başlığa ayrılır. Bunlar; zaman olarak boş zaman, aktivite olarak boş zaman, rekreasyon olarak boş zaman ve yaşam biçimi olarak boş zamandır.

\section{REKREASYON KAVRAMI}

Rekreasyon kavramı günümüzde pek çok yerde en sık kullanılan kelimelerden biri haline gelmiştir. Hatta pek çok insan boş zaman ve rekreasyon kelimesini bir diğerinin yerine kullanmaktadır. Ancak, bu iki kavram her ne kadar da birbiri ile yakından ilişkili olsa da farklı anlamlar taşırlar (Karaküçük ve Gürbüz, 2007: 30). Rekreasyon birçok anlamın yüklendiği ve kapsamına çok çeşitli aktivitelerin alındığı, sıkça kullanılan bir kavramdır. Simmons (2000)'a göre, rekreasyon kişiyi yenileyen keyifli ve sosyal bir aktivite olarak kabul edilebilir. Ancak hangi faaliyetlerin rekreasyon olduğuna dair fikir birliği yoktur (Brey ve Lehto, 2007).

Rekreasyon kavramının tanımlanmasında birçok rekreasyon teorisi, oyun ve rekreasyonu bir ve aynı kavram olarak değerlendirirken, bazıları ise farklı kavramlar olduğunu belirtmekte ve rekreasyonun bir yetişkin aktivitesi oyunun ise bir çocuk aktivitesi olduğunu savunmaktadır (Torkildsen, 1993: 64). Rekreasyon kelimesi, Latince yeniden yaratma tazelenme anlamindaki recreare kelimesinden türetilmiştir. Daha sonraki yıllarda çeşitli sözlüklerde "manevi gücün ya da ruhun canlandırılması yeniden doğum" anlamında ifade edilmiştir. Gerçekte rekreasyon bir yenilenme deneyimi, günlük rutinden kaçış, canlanma ve değişime karşılık gelmektedir (Jensen ve Guthrie, 2006:17). Tanımlarda rekreasyonun özellikle canlanmaya ve yenilenmeye etkisi aktarılmıştır. Dolayısıyla rekreasyon tanımlanırken insanları iş için yenileyen bir aktivite olarak sınırlandırılmıştır (Torkildsen, 2005: 52). 
Türkçe karşılığında yaygın bir şekilde boş zamanları değerlendirme olarak kullanılan rekreasyon bireylerin ya da toplumsal kümelerin boş zamanlarında gönüllü olarak yaptıkları dinlendirici ve eğlendirici faaliyetler anlamını barındırmaktadır (Karaküçük, 2008: 59). Parker (1979: 20)'a göre rekreasyon, etkinliklere katılanlara mutluluk, tatmin, ruhsal denge, karakter, rekabet etme gücü, ruhsal dinginlik, özgürlük, fiziksel ve sosyal aktivite ve entelektüel bakış açısı kazandıran etkinliklerdir (Gül, 2014: 11). Bayer (1964: 49) rekreasyonu; yaşamsal fonksiyonları canlı tutarak bireyleri dinlendiren, eğlendiren, neşe veren ve çeşitli uğraşlardan haz almalarını sağlayan eylemleri yapmak veya bu etkinliklere katılarak fiziksel ve ruhsal canlanma sağlamak olarak tanımlamaktadır (Şahbaz ve Altınay, 2015). Literatürde yer alan tanımlamalara dayanarak rekreasyon; kişilerin zorunlu zamanları ve eylemleri dışında zihinsel ve fiziksel olarak yenilenmek üzere aktif ya da pasif olarak katıldıkları etkinlikler şeklinde tanımlanabilmektedir.

\section{REKREASYONUN ÖZELLIKLERİ}

Rekreatif etkinlikler, bireyin yaşamındaki birçok sıkıntıdan kurtulmasını ve bireyin kendisini geliştirmesini sağlayarak, kendisini, ilişkilerini ve sosyo-kültürel uyumunu olumlu yönde etkilemektedir (Tütüncü vd., 2011). Yapılan rekreasyon tanımları ile bağlantılı olarak, rekreasyon aktivitelerinin katılanlara mutluluk, tatmin, yaratıcllı, ruhsal denge, karakter, rekabet etme gücü, ruhsal kapasite, özgürlük, fiziksel ve ruhsal kondisyon ve daha geniş dünya görüşü kazandırması gerektiği ortaya çıar (Hacıoğlu, Gökdeniz ve Dinç, 2009: 30).

Rekreasyonun birçok araştırmacı (Hazar, 2003; Jensen ve Guthrie, 2006; Karaküçük, 2008; McLean, Hurd ve Rogers, 2008; Hacıŏlu vd., 2009; Sevil, 2012) tarafından kabul edilen bazı temel özelliklerinden bahsetmek mümkündür. Buna göre rekreasyonun temel özelliklerini şunlar oluşturmaktadır (Karaküçük, 2008: 69; Hazar, 2003: 27):

- Rekreasyon faaliyetleri her yaştaki bireylerin istek ve ilgilerine göre gönüllü olarak boş zamanlarında katıldıkları ve insanlar üzerindeki olumlu etkileri yaş, gelir, meslek, ihtiyaç vb. faktörlere göre değişiklik gösteren etkinliklerdir.

- Rekreasyonel faaliyetler toplumun geleneklerine, törelerine, ahlaki ve manevi değerlerine uygun olarak ve sosyal değerlere ters düşmeden her türlü açık veya kapalı alanlar ile her mevsim ve iklim şartlarında uygulanabilmektedir.

- Rekreasyon, rekreatif etkinliklere katılma sonucu ortaya çıkan bir deneyimdir ve haz ve neşe sağlayan çok çeşitli faaliyetler içerir.

- Rekreasyon bir faaliyeti gerektirir ve katılımcılar zamanı, etkinlik türünü ve yeri kendileri seçer, bir faaliyet yapılırken, ikinci veya daha fazla faaliyetlere de ilgi duyma veya gerçekleştirme imkânı verir.

- Rekreasyonun her kişiye göre bir amacı vardır ve etkinliklerin belirlenmesinde insan ihtiyaçları dikkate alınmalıdır.

- Rekreasyon özgürlük hissi verir ve insanların başarı kazanma, kendini kanıtlama, kişiliğini ifade etme, takdir edilme, toplumsal statü kazanma, yeni deneyimler edinme ihtiyaçlarına yöneliktir.

- Rekreasyon eylemi, planlı veya plansız, beceri sahibi kişilerle veya beceri sahibi olmayan kişilerle ya organize ya da organize olmamış mekânlarda yapılabilir.

Sonuç olarak rekreasyon; boş zamanlarda, araçlı, araçsız, açık veya kapalı alanlarda, kent içi veya kent dışında, bir organizasyon içinde ya da dışında zorunlu olmadan seçilen zevk ve neşe verici her türlü etkinliklerden oluşmaktadır (Karaküçük, 2008:75). 


\section{REKREASYON FAALIYYETLERININ SINIFLANDIRILMASI}

Rekreatif etkinlikler çok farklı metotlarla çok farklı biçimlerde sınıflandırılabilirler. Mekâna göre, zamana göre, eylem çeşidine göre, yapılış şekline göre; bireysel, bedensel, zihinsel, tedavi edici, amaçlarına göre şeklinde çoğaltılabilir. Her rekreatif etkinliğin gurubu bireyin bu etkinlikten beklentisine ve katılım biçimine göre değişir. Bu etkinlikler amaçlarına ve işlevlerine bağlı olarak da sınıflandırılırlar. Dinlenme, kültürel, toplumsal ilişkiler kurmak, sportif, turizm ve sanatsal amaçlı yapılıyor olabilirler (Mull vd., 1997: 4-5).

Rekreasyonun sınıflandırılmasında, esas alınan prensip, kişinin rekreasyon faaliyetlerine katılmasına sebep olan amaçlar, istekler ve zevkler olmalıdır (Karaküçük, 2008: 76). Rekreasyon çeşitlerinin sınıflandırılmasında katılımcı özellikleri, amaç, mekân vb. kriterler rol oynamaktadır. Yapılan bu sinıflamalarda göz ardı edilmemesi gereken husus, yapılan rekreasyonel faaliyetlerin birden çok sınıflamanın içerisinde yer alabileceğidir (Sevil, 2012: 15). Örneğin golf, kayak gibi etkinlikler hem açık alan rekreasyonu hem de sportif rekreasyon grubunda yer almaktadır (Yüncü, 2013: 11). Bu durumun nedeni rekreasyonun çok yönlü olmasıdır. Bu nedenle kesin sinıflandırma yapmak çok zordur (Hazar, 2003: 22).

Tribe, (1995: 2) rekreasyonu evde yapılan rekreatif etkinlikler, ev dışında yapılan rekreatif etkinlikler ve seyahat ve turizm olarak üç grupta incelemektedir. Hazar, (2003: 22) etkinliklere katılma şekli, mekân, katılımcıların milliyetleri, yaşları, sayısı ve fonksiyonel açıdan olmak üzere sinıflandırmaktadır. Karaküçük, (2008: 76) rekreasyonel etkinlikleri bu tür etkinliklere katılan bireylerin amaçları, istekleri ve zevklerinin farklılaşması nedeniyle sınıflandırmanın da bu anlamda değişik kategorilerde yapılması gerektiğini vurgulamaktadır.

Tablo 1: Rekreasyon Faaliyetlerinin Sınıflandırılması

\begin{tabular}{lllll}
\hline $\begin{array}{l}\text { Katılım Şekline } \\
\text { Göre }\end{array}$ & $\begin{array}{l}\text { Mekâna } \\
\text { Göre }\end{array}$ & Milliyete Göre & $\begin{array}{l}\text { Katılımcı } \\
\text { Sayısına } \\
\text { Göre }\end{array}$ & $\begin{array}{l}\text { Fonksiyona } \\
\text { Göre }\end{array}$ \\
\hline $\begin{array}{l}\text { Aktif (Etken) } \\
\text { Pasif (Edilgen) }\end{array}$ & $\begin{array}{l}\text { Açı Alan } \\
\text { Kapalı Alan }\end{array}$ & $\begin{array}{l}\text { Ulusal } \\
\text { Uluslararası }\end{array}$ & $\begin{array}{l}\text { Bireysel } \\
\text { Grup }\end{array}$ & $\begin{array}{l}\text { Ticari, Estetik, } \\
\text { Sosyal, Sağlık, } \\
\text { Fiziksel, Sanatsal, } \\
\text { Kültürel, Turistik. }\end{array}$ \\
\hline
\end{tabular}

Kaynak: Hazar, 2003: 22; Karaküçük, 2008: 77; Karaküçük ve Akgül, 2016: 60.

\section{TURİZM KAVRAMI}

Turizm kavramına ilişkin olarak yürütülen her çalışmada ilk ve en büyük zorluk, turizm tanımının net bir şekilde yapılamamasından kaynaklanmaktadır. Turizm kelimesinin Latincede dönmek, etrafında dolaşmak, geri dönmek anlamına gelen "tornus" kökünden üretildiği söylenmektedir (Sezgin, 2001: 13). Turizm, insanların kendi konaklama yerleri (yaşadıkları yer) dışında, sürekli yerleşmemek, özellikle politik ve ticari bir amaç gütmemek üzere; iş, merak, din, sağllk, spor, istirahat kültür ve snobizm gibi amaçlarla veya aile ziyareti, kongre ve seminerlere katılma gibi nedenlerle, kişisel ya da toplu bir şekilde yaptıkları seyahatlerden ve gittikleri yerde yirmidört saati aşan konaklamalarından ortaya çıan iş ve münasebetleri kapsayan sosyal bir olaydır (Sağcan, 1986: 80). 
Dünya Turizm Örgütü (WTO)'nün tanımına göre turizm; sürekli kalışa dönüşmemek ve gelir getirici hiçbir uğraşıda bulunmamak şartı ile bireylerin geçici süre konaklamalarından doğan olay ve ilişkilerin tümüdür (Sarı ve Özüpek, 2011: 28). Yapılan tanımlar da ortak olan nokta; insanların geçici olarak boş zamanlarında, kâr amacı gütmeden, sürekli yaşadıkları mekânın dışında zaman geçirerek, tek başına veya toplu olarak yapılan seyahat ve konaklamalı faaliyetlerdir.

Turizm tanımı içerisinde şu özellikler bulunmaktadır:

- Turizm, kişilerin sürekli olarak yaşadıkları yerin dışında olan bir olayıdır.

- Turizm olayında seyahat nedeninin geçici olması gerekmektedir.

- Turizmde seyahat nedeninin bir yerde çalışmak, iş yapmak amacı olmaması gerekir.

- Turizm olayına katılan kişilerin gittikleri yerde tüketici durumunda olması gerekir.

- Turizm olayında yapılan geçici konaklamadan sonra sürekli ikamete geri dönülmesi gerekmektedir.

Bu ögelerinde yer aldığı ortak noktalar itibari ile turizmin genel olarak tanımı; daimî olarak ikamet edilen yerler dışında ziyaretçi ve tüketici olarak tatil, eğlence, dinlence kültür vb. gereksinimlerin giderilmesi için yapılmış olan seyahat ve geçici konaklama hareketleri olarak yapilabilir (Gürbüz, 2002: 50).

\section{REKREASYON VE TURİZM ARASINDAKİ İLIŞKİ}

Turizm ve rekreasyon genel olarak insanların hayat kalitesini artırarak, tatmin düzeylerini etkilemektedir. Dolayısıyla rekreasyon ile turizm arasında ortak bir yaşam ilişkisi ortaya çıkmaktadır. Bu nedenle, rekreasyon ve turizm arasındaki ilişki ve etkileşimler giderek artan bir ilgiyle araştırma konusu yapılmaktadır (Karaküçük, 2008: 187).

Turizmi, rekreasyonu içine alarak ya da rekreasyonu, turizmin kapsamına alarak yapılan çok sayıda tanım, analiz veya değerlendirmelere rastlamak mümkün olmaktadır. Bu değerlendirmeler daha çok turizm veya rekreasyona temel olarak hangi pencereden bakıldığı ile ilgilidir (Karaküçük ve Akgül, 2016: 109).

Rekreasyon ve turizm arasındaki ilişki özellikle her iki alanında tanımlarında boş zaman kavramının kullanılması ile fark edilmektedir. Ayrıca gerçekleştirilen etkinlikler açısından turizm ve rekreasyon arasında yine yakın bir ilişkiden bahsetmek mümkündür.

Turizm hareketinin sınırlarını çizmek ve neyin turizm sayılıp neyin turizm sayılmadığına karar vermek, bilim insanlarının uzun süredir tartıştıkları bir konudur. Turizm tanımlarının birçoğu; rekreasyon ve boş zaman kavramlarının içinde kalmaktadır. Bu bağlamda turizm; rekreasyon ve boş zaman kavramları ile güçlü karakteristik özellikler ve teorik temeller paylaşmaktadır (Swarbrooke vd., 2003: 5). Rekreasyon ve turizm kavramları çoğunlukla aynı kaynakları paylaşmakta, aynı alanları kullanmakta, benzer tüketicilerin bütçelerinden yararlanmak için yarışmakta ve katılımcılara benzer sosyal ve psikolojik etkiler yaratmaktadır (Çetinkaya, 2014: 10). Bununla birlikte rekreasyon ve turizm kavramları birbirlerinden ayrı ancak birbirleri ile ilişkili kavramlar olarak algılanmışlardır (Brey ve Lehto, 2007).

Rekreasyon ve turizm arasında bir ortak yaşam ilişkisinden söz edilmektedir. Turizm dinlenme, eğlenme amacı taşıyan, boş zamanları değerlendirme ihtiyacından kaynaklanmaktadır. Rekreasyon imkânlarındaki gelişme o bölgeyi daha çekici kılarak, bölgeye daha çok turistin 
gelmesi ve bölgenin gelirinin artmasına neden olabilmektedir (Karaküçük, 2008: 210). Turizm ve rekreasyon ilişkilerini içeren çalışmalar incelendiğinde, rekreasyon alanlarının planlanması ve kararların alınması, inşa edilen mekânsal yapılar ve rekreasyonel yapılara erişim gibi unsurların yer aldığ1 görülmektedir (Metin, Kesici ve Kodaş, 2013).

\section{Rekreasyon ve Turizm Kavramları Arasındaki Benzerlikler}

Rekreasyon ve turizm insanların boş zamanlarında gerçekleştirdikleri faaliyetleri kapsamaktadır. Dolayısıyla turizm ve rekreasyon aynı türden birçok ekinliği paylaştıkları için birbirleriyle örtüşmektedirler. Turizm ve rekreasyon arasındaki benzer noktalar şu şekilde özetlenebilir (Hazar, 2003: 30; Karaküçük, 2008: 211; Koyuncu, 2012: 30):

- Her iki olguda, yani gerek turizm gerekse rekreasyon katılımcıların kişisel istekleri sonucu ortaya çıar.

- Her iki etkinlikte de katılım gönüllülük esasına dayalıdır ve zorlama yoktur.

- Her iki kavramda fiziksel veya düşünsel bir hareketlilik içerir.

- Her iki etkinlikte boş zamanlarda yapılır.

- Her yaştaki ve sosyal yapıdaki bireylerin katılımı söz konusudur.

- Her iki etkinlikte bireysel veya toplu olarak yapilabilir.

- Turistlerin ve rekreasyonistlerin katıldığı aktiviteler dikkate alındığında her iki grubunda çoğu zaman aynı aktiviteye katıldığı görülür.

- Hem rekreasyon hem de turizm sürekli bir aktivite değildir, her ikisi de büyük oranda değişen ekonomik durumlara, modalara, gelenekler, sosyo-politik hususlara, eğitim ve hükümet politikalarına, tanıtım faaliyetlerine bağlı olarak gelişir ve değişir.

- Çevreyi geliştirmek, ulusal mirası korumak ve restore etmek için harcanan çabalar, turizm ve rekreasyona katkı sağlar.

- Yerel rekreasyon için yüksek kaliteli kullanımlar, genelde turizme ilgiyi artırır ve konaklama ve diğer hizmetler için talep oluşturur.

- Bir yöre veya ülkedeki insanların rekreasyona yönlendirilmesi, turistik rekreasyonun dolayısıyla iç turizmin gelişmesini sağlar.

\section{REKREASYON VE TURIZM KAVRAMLARI ARASINDAKİ FARKLILIKLAR}

Birbirine yakın ve iç içe geçmiş kavramlar olan turizm ve rekreasyon arasında bazı temel farklılıklar bulunmaktadır. Rekreasyon daha kısa süreli, turizm ise daha uzun süreli boş zamanların kullanılması şeklinde gerçekleştirilmektedir. Turizm, tüketicinin onu elde edebilmesi için sürekli yaşanılan yerden ayrılmayı gerektirir ve esas unsur konaklamadır, oysa rekreasyonel etkinliklerde böyle bir zorunluluk bulunmamaktadır.

Rekreasyon faaliyetlerini turizmden ayıran en belirgin aktivite grubunu kent dışı açık alan etkinlikleri oluşturmaktadır. Outdoor aktivite yapan rekreasyonistler günübirlik veya birkaç gün süren faaliyetlerde genellikle turistlerin aksine gittiği bölgeden konaklama ve benzeri bir hizmet ya da ürün satın almaz (Karaküçük ve Akgül, 2016: 125). Arz ve talep açısından bakıldığında da turizm ve rekreasyon faaliyetleri arasında farklılıklar göze çarpmaktadır. Turizm arzı bir ülkenin bütününü kapsarken, rekreasyon alanlarında arz genellikle yerleşik nüfusa yöneliktir. Bu durumda rekreasyonel etkinliklere katılanlar ikamet ettikleri yerlerden uygun mesafelere yerleştirilmiş olan imkân ve çekicilerle sınırlandırılmışlardır. Bu açıdan rekreasyon daha çok yerel olarak değerlendirilir. 
Turizmde kaynaklar ağırlıklı olarak farklı dönemleri kapsayan sezonlarda kullanılırken, rekreasyonda kaynakların kullanımında bir süreklilik vardır ve kısa tatil dönemleri ile özellikle hafta sonlarında yoğunluk görülür. Hizmet alımı açısından turizmde ağırlıklı olarak ulusal ve uluslararası düzeyde kurulmuş olan ticari aracılar kullanılırken, rekreasyon faaliyetlerinde hizmete erişim daha çok bireyseldir. Turizm para ve zaman harcama bakımından büyük bir satın alma olayıdır. Turizmde harcanabilir gelirin olması öncelikliyken rekreasyon faaliyetlerinde hizmet sunumu kamu ağırlıklı ve ücretsizdir.

Mieczkowski, (1990: 35); turizm ve rekreasyon arasındaki farklılıkları şu şekilde açıklamaktadır:

- Turizm, sadece boş zamanla ilgili değil aynı zamanda çalışma zamanı ile de ilgilidir. Fakat rekreasyon, tamamen boş zaman süresince ortaya çıkar.

- Turizmde rekreasyondan farklı olarak, katılımcıların yaşadıkları mekânın dışına çıkmaları, geçici yer değiştirmeleri gerekmektedir.

- Turizm ve rekreasyon sadece anlamları bakımından değil aynı zamanda uygulamada da farklılıklar göstermektedirler. Rekreasyonel ekipmanların satın alımı, turizm için ayrılmış fonla birlikte aile bütçesinde uyuşmazlık yaratabilir.

- Turizm (ve turizm endüstrisi) çok kesin olarak ticari anlamda ekonomi ile aynı anlamı ifade etmektedir. Rekreasyonun da ekonomik etkileri vardır, ancak rekreasyon özellikle devlet, sosyal organizasyonlar, işverenler vb. tarafından ücretsiz olarak sağlandığında rekreasyonun da ticari yönleri daha zayıftır.

- Rekreasyonun turizmden farklı diğer bir yanı, zamanla özel ustalık elde edilmesini gerektiren aktivitelerin merkezinde yer almasıdır.

\section{SONUÇ VE ÖNERİLER}

$\mathrm{Bu}$ çalışmada, turizm ve rekreasyon kavramları ele alınmış, bu kavramlar arasındaki ilişki karşılaştırılarak analiz edilmiştir. Turizm ve rekreasyonun ilişkileri ve farklılıklarından da anlaşılabileceği üzere; bu iki kavramın kesin bir şekilde birleştirilmesi veya birbirinden ayırılması oldukça zordur.

Turizm ve rekreasyonun ortak noktaları olduğu gibi her ikisinin de birbirinden farklı yönleri de vardır. Gerek turizmde gerekse rekreasyonda kaynaklar ortaktır ve amaç benzerliği söz konusudur. Dolayısıyla, birbirinin yerine kullanılması, birbirinin içerisine yerleştirilmeye çalışılması ve aynı anlamı ifade ettiğini söylemek olanaksızdır. Turizm ve rekreasyon arasındaki ilişkiye yönelik literatür incelendiğinde turizm kavramı ve turistik faaliyetlerin rekreasyonu kapsadığı veya turizm ve rekreasyonun birbiri ile ilişkili ancak farklı disiplinler olduğunun savunulduğu da görülmektedir. Her iki kavramın boş zamanda yapılıyor olmaları, yenilenme ihtiyacı gibi ortak noktaları olduğu ancak turizmde seyahat ve konaklama olgusu varken rekreasyonda böyle bir zorunluluğun olmaması gibi her ikisinin de kesin çizgilerle birbirinden ayrıldığı alanların var olduğu söylenebilir.

Turizm ve rekreasyon arasındaki yakın ilişkiye rağmen bazı farklılıklarda bulunmaktadır. Turizm talebi, ülkenin farklı bölgelerinden veya diğer ülkelerden kaynaklanırken, rekreasyon talebi, belirli bir yerde ikamet eden yerleşik nüfus tarafından oluşturulmaktadır. Turizm aktiviteleri konaklama özelliği açısından rekreasyonel faaliyetlerden daha uzun bir zamanı gerektirmektedir. 
Bir destinasyonda turizmin gelişmesinde rekreasyonel faaliyetlerin önemli bir yeri bulunmaktadır. Bir destinasyonun turizm potansiyelini doğal güzellikler (ormanlar, nehirler vb.), tarihi zenginlikler (tarihi kalıntılar, kaleler ve diğer antik mimari eserler vb.), kültürel değerler (dini değerler, fuarlar, festivaller, el sanatları vb.), yapay değerler (tema parkları vb.) oluşturmaktadır. Bu açıdan yöneticiler turistik gelişmeye etkisi açısından rekreasyonel faaliyetlerin ve rekreasyon alanlarının önemini kavramalıdırlar. Bu bağlamda çekicilik unsuru olarak rekreasyonel etkinlikler turizmi geliştirici amaç ve faaliyetleri doğrultusunda turizm ile ilişkili olarak ortak amaç doğrultusunda geliştirilmelidir.

Sonuç olarak genel kanı iki kavram arasında yakın bir ilişkinin olduğu fakat farklı disiplinler olduğu yönündedir. Bu kapsamda çalışmanın, turizm ve rekreasyon arasındaki ilişkiye dikkat çekerek benzer araştırmalara kaynak teşkil edeceği düşünülmektedir.

\section{KAYNAKÇA}

Aytaç, Ö. (2006). Tüketimcilik ve Metalaşma Kıskacında Boş Zaman. Kocaeli Üniversitesi Sosyal Bilimler Enstitüsü Dergisi, 1(11), 27-53.

Brey, E. T. and Lehto, X. Y. (2007). The relationship between Daily and Vacation Activities. Annals of tourism Research, 34(1), 160-180.

Cordes, K. A., and İbrahim, H. M. (2003). Applications in Recreation and Leisure: For Today and The Future (Third Edition ). McGraw-Hill.

Çetinkaya, G. (2014). Doğa Yürüyüşü Parkurlarının Turizm Amaçlı Değerlendirilmesi: Antalya Beydağları Örneği. Akdeniz Üniversitesi Sosyal Bilimler Enstitüsü, Antalya.

Demir, C. ve Çevirgen, A. (2006). Turizm ve Çevre Yönetimi. Ankara: Nobel Yayın Dağıtım.

Erol, M. (2003). Turizm Pazarlaması. İstanbul: Ekin Kitabevi.

Gökmen, H., Açıalın, A. ve Koyuncu, N. (1985). Yükseköğrenim Öğrencilerinin Serbest Zaman Etkinlikleri ve Kendilerini Gerçekleştirme Düzeyleri. Ankara: Milli Eğitim Basımevi.

Göral, Ş. (2013). İnternet Ortamında Geçirilen Boş Zamanın Üniversite Öğrencilerinin Mutluluk Ve Yaşam Doyum Değerlerine Etkisi. T.C. Gazi Üniversitesi Sağlık Bilimleri Enstitüsü, Ankara.

Gül, T. (2014). Rekreasyon Olgusuna Genel Yaklaşım. A. Yaylı (Editör), Rekreasyona Giriş. Ankara: Detay Yayıncilik, s. 1-67.

Gürbüz, A. (2002). Turizmin Sosyal Çevreye Etkisi Üzerine Bir Araştırma. Teknoloji Dergisi (1-2), 49-59.

Hacıoğlu, N., Dinç, Y. ve Gökdeniz, A. (2009). Boş Zaman ve Rekreasyon Yönetimi. Ankara: Detay Yayıncilik.

Hazar, A. (2003). Rekreasyon ve Animasyon (2. Baskı). Ankara: Detay Yayıncılık.

Jensen, C. R. and Guthrie, S. (2006). Outdoor Recreation in America (6th ed.). Champaign, IL: Human Kinetics.

Karaküçük, S. (1999). Rekreasyon Boş Zamanları Değerlendirme. Ankara: Gazi Kitabevi.

Karaküçük, S.(2008). Rekreasyon: Boş Zamanları Değerlendirme. Ankara: Gazi Kitabevi.

Karaküçük, S. ve Akgül, B. M. (2016). Ekorekreasyon Rekreasyon ve Çevre, Ankara: Gazi Kitabevi. 
Karaküçük, S. ve Gürbüz, B. (2007). Rekreasyon ve Kent(li)leşme. Ankara: Gazi Kitabevi.

Koyuncu, İ. (2012). Rekreasyon Potansiyelinin Belirlenmesi Üzerine Bir Araştırma; Aksaray Güzelyurt İlçesi. Ankara: Ankara Üniversitesi Fen Bilimleri Enstitüsü.

Lundberg, D. E. (1980). The Tourist Business. Boston: CBI Publishing Inc.

Mannell, R. C. and Iso-Ahola, S. (1987). Psychological Nature of Leisure and Tourism Experience. Annals of Tourism Research, 14(3), 314-331.

McLean, D. D., Hurd, A. R. and Rogers, N. B. (2008). Krau's Recreation and Leisure in Modern Society (8th Edition ). London: Jones And Bartlett Publishers Inc.

Metin, T. C., Kesici, M. ve Kodaş, D. (2013, Nisan). Rekreasyon Olgusuna Akademisyenlerin Yaklaşımı. Journal of Yaşar University, 30(8), 5021-5048.

Mieczkowski, Z. (1990). World Trends in Tourism and Recreation. New York: Peter Lang Publishing. Mull, R. F., Bayless, K. G., Ross, C. M. and Jamieson, L. M. (1997). Recreational Sport Management (Third Edition ). Human Kinetics.

Sağcan, M. (1986). Rekreasyon ve Turizm. İzmir: Cumhuriyet Basımevi.

Sarı , G. ve Özüpek, N. (2011). Seyahat Acentalarında Uygulanan Halkla İlişkiler Faaliyetlerinin İç Tanıtıma Etkisi: Manavgat Örneği. Ticaret ve Turizm Eğitim Fakültesi Dergisi (1), 25-45.

Sevil, T. (2012). Boş Zaman ve Rekreasyon: Kavram ve Özellikler. S. Kocaekşi (Editör), Boş Zaman ve Rekreasyon Yönetimi. Eskişehir: T.C. Anadolu Üniversitesi, s. 2-25.

Sezgin, O. M. (2001). Genel Turizm ve Turizm Mevzuatı. Ankara: Detay Yayıncllı.

Swarbrooke, J., Sakal, C., Leckie , S. and Pomfret, G. (2003). Adventure Tourism. Oxford: Butterworth-Heinemann.

Şahbaz, P. R. ve Altınay, M. (2015). Türkiye'deki Milli Parkların Rekreasyon Faaliyetleri Açısından Değerlendirilmesi. Journal of Tourism and Gastronomy Studies, 3(3), 125-135.

Torkildsen, G. (1993). Leisure and Recreation Management (Third Edition ). London: Spon Press.

Torkildsen, G. (2005). Leisure and Recreation Management (Fifth Edition ). London And Newyork: Taylor and Francis Group.

Toskay, T. (1989). Turizm: Turizm Olayına Genel Yaklaşım. İstanbul: Der Yayınları.

Tribe, J. (1995). The Economics of Recreation, Leisure and Tourism. Oxford: Butterworth-Heinemann Ltd.

Türkmen, İ. (1999). Yönetsel Zaman ve Yetki Devri Açısından Yönetimde Verimlilik. Ankara: MPM Yayınları.

Tütüncü, Ö., Aydın, İ., Küçükusta, D., Avcı, N. ve Taş, İ. (2011). Üniversite Öğrencilerinin Rekreasyon Faaliyetlerine Katılımını Etkileyen Unsurların Analizi. Spor Bilimleri Dergisi, 2(22), 69-83.

Uğurlu, A. (2005). Rekreasyonel Amaçlı Doğa Sporlarının Turizmde Kullanılması Antalya Köprülü Kanyon Rafting Uygulaması. Antalya: T.C. Akdeniz Üniversitesi Sosyal Bilimler Enstitüsü.

Yüncü, D. (2013). Boş Zaman ve Rekreasyon: Kavram ve Özellikler. M. Argan (Editör), Rekreasyon Yönetimi. Eskişehir: T.C. Anadolu Üniversitesi, s. 2-29. 